Al-Manhaj: Journal of Indonesian Islamic Family Law, 3 (1), 2021: 81-105

ISSN: 2715-003; E-ISSN 2714-5514

DOI: http://dx.doi.org/10.19105/al-manhaj.v3i1.4212

\title{
The Problem of Underhand Marriage (Sirri) in Coastal Java Pati
}

\author{
A. Zaenurrosyid, Abdul Kahfi, Ali Syafa' \\ (Universitas Islam Sultan Agung (UNISSULA) Semarang \\ zaenurrosyid@unissula.ac.id)
}

\begin{abstract}
Abstrak:
Dinamika hukum Islam mengalami tantangan beragam di Nusantara. Pernikahan di Pesisir Jawa menjadi problematis karena dilarang dalam hukum positif, namun dibolehkan dalam Islam. Penelitian ini dengan pendekatan kualitatif dalam perspektif sosio-normatif. Ditemukan beberapa kasus pernikahan bawah tangan di Pesisiran Jawa, Pati dengan keragaman alasan suami istri menikah dibawah tangan. Faktor yang dominan adalah persoalan ekonomi, hamil di luar nikah, maupun alasan study. (The dynamics of Islamic law face various challenges in the archipelago. Marriage on Marriage on the coastal Java becomes problematic because it is prohibited in positive law, but is allowed in Islam. This research applied a qualitative approach in a socio-normative perspective. Several Cases of underhand marriages have been found in coastal Java, Pati with a variety of reasons for husband and wife marrying on underhand. The dominant factors are economic problems, pregnancy out of wedlock, and study reasons.)
\end{abstract}

\section{Kata Kunci:}

Hukum Islam, Pernikahan Sirri, Hukum Positif, Pesisiran Pati

\section{Introduction}

Men and women have a desire to always have a relationship between one person and another in an instinctive relationship, meaning that a man needs love from the opposite sex, namely a woman to be a life partner. Likewise, women who need a man to be their life 
companion 1 . In article 1 number one of 1974 it is formulated that marriage is a relationship between men and women as a life partner who has an orientation to build a prosperous and devout family to $\operatorname{God}^{2}$.

Based on the law of 1975, article 2 paragraph 1, it is also stated that a valid marriage is when its implementation is carried out that based on their respective religions and beliefs. Marriage is intended to build a happy family sakinah, mawaddah, warahmah. Anne-Marie interpret the marriage contract as a solid bond and based on love. In 1974 law number 1 article 10, the blessing is formulated by husband and wife to have a noble obligation, to uphold the household, which is the foundation of society.

As for article 31, it is known that the rights and position of the wife are balanced with the rights and positions of the husbands in terms of life and social life together in society.Each of which has the right to take legal actions that the husband is the head of the household and the wife is the housewife. According to Arso Sastrodimedjo and Wasit Aulawi (1978: 93) that the husband and wife couple are obliged to give love and respect and help each other well (bil ma' ruf). Article 32 also states that a married couple should have a residential house, while the (house) referred to in Article 1, it is agreed upon with a spouse marriage is a very strong contract (misaqon gholizhon), to wait for Allah's orders and carry it out as worship 3 .

Marriage is linguistically defined as a struggle with syar'i meaning as a contract that guarantees the halal relationship between a man and a woman in a husband and wife relationship and guarantees the legitimacy of married life. Thus, the marriage embodies a good household as, in Article 4; it is stated that marriage is valid, if it is carried out in accordance with Islamic law. Based on the law on marriage in paragraph 1 , article five states that there is an orderly marriage in a muslim community, then the marriage must be registered. And in article 2, it is stated that the recording is carried out

\footnotetext{
${ }^{11}$ Zuhdi Muzhar, Memahami Hukum Perkawinan Islam, (Yogyakarta: Al-Bayan, 1994), 80 2 Soemiyati , Hukum Perkawinan Islam dan Undang-Undang Perkawinan (UUP No. 1 Tahun 1974), (Yogyakarta: Penerbit Liberti, 1982), 97-99.

3 Wahbah al-Zuhaili, Al-Tafsir al-Munir fi al-Aqidah Wa al-Syari' ah wa al-Manhaj, (Beirut: Dar al-Fikr al-Muasir, tt.), 76-83.
} 
by the employees of the Islamic religious office, as regulated in law number 22 of 1946 and also law number 32 of 1954.

In law number 32 of 1954 in article 7, it is stated that the first marriage which is proven by a marriage contract is made by a marriage registrar (PPN). Second, if the marriage cannot be proven by a marriage certificate, the husband and wife can apply for the marriage certificate to the religious court. Third, determination of marriage (isbat nikah) is more limited to marriage in completing the divorce, the disappearance of the marriage certificate, doubts about whether or not one of the conditions of marriage is valid, the existence of a marriage that occurred before the enactment of law number 1 of 19744 . Then their marriage is carried out, it may not fulfill the legal barrier to marriage. Fourth, those who have the right to apply for an determination of marriage (itsbat nikah) are the husband and wife of their children as the guardian of marriage and the parties having an interest in the marriage.

There are various problems of marriage under the authority of the coastal Java region, to be exact, in Jakenan sub-district, there are several cases of illegal marriage as has been prohibited by the government ${ }^{5}$. Marriage is born in the context of the large number of people who carry out underage marriages so that many women who are 10 years old have been married, this decreases the quality of women and implies an increase in the intensity of marriage and it is not their own wish. On the other hand, parents also want their children to get married soon so that they feel more successful when delivering educating, raising their daughters ${ }^{6}$.

Many divorces are carried out arbitrarily, because there are no controlling regulations. So, women at that time were mostly unprotected and their position in marriage also divorce when the law was passed, the figure was almost $60 \%$. With so many irresponsible

\footnotetext{
${ }^{4}$ K. Wijk Saleh, Himpunan Peraturan Dan Undang-Undang Tentang Perkawinan, Jakarta: (PT. Iktiar Baru Van Hoven, 1974), 77-85.

5 Based on data from the Marriage Certificate Document at the KUA Jakenan District, and interviews with the staff of the religious affairs office, there are still cases of underhand marriage (sirri) held by the community, either known or kept secret from the community.

${ }^{6}$ Muallif Sahlany, Perkawinan dan Problematikanya, (Yogyakarta: Sumbangsih Offset, 1981), 23-56.
} 
polygamy, sometimes a wife does not know that she is the 4th wife and only finds out after knowing the birth of a child from another wife.

Mahdian emphasized that the marriage law has been triggered for a long time. In the community there are still many who do not know and understand the existence of the marriage law. Because the counseling that is carried out is still incidental and not yet sustainable, but the community still chooses this method. And in a pragmatic way it is important to have a legal basis religiously in their marriage. The other causative factor is that marriages can also be carried out secretly under the hand, even the marriage also opens opportunities by involving various parties who think that under hand marriage (marry sirri) is a solution to bad behavior such as adultery, for example?

In the Indonesian context, this problem gets legal support for marriage law. But its enforcement has not been effective and intensively implemented in all levels of society, besides the absence of sanctions for those who violate it in the form of administrative and other sanctions. In the marriage law, women actually have the power to fight for their rights, because women do not fully have awareness of their rights in this marriage law. So that, women have the same knowledge and rights in marriage, work or other justice.

This marriage is realized to increase harmony in the household, so in those matters, this study tries to discuss how the problems of marriage in the context of today's society, to describe of under hand marriage are carried out from the view of Islamic law, and to analyze the dynamics of implementation and factors background of under hand marriage (sirri) in the coastal areas of south Pati, Central Java ${ }^{8}$.

\section{Nikah Sirri and Official Marriage from Islamic Perspective and Positive Marriage Law.}

In the conception of marriage, namely in view of the sharia Islamic law and Marriage Law No.1 of 1974, it is explained that marriage is linguistically defined as sexual relations and is metaphorically as a

\footnotetext{
7 Sudarsono, Perkawinan Nasional, (Jakarta: Rineka, 1991), $42-47$.

8 Based on data documented in the Annual Report Book of the KUA Jakenan Diktat District Towards Marriage, BP4 Kab.Pati. There are several cases of underhand marriage. Based on the information from the KUA staff, this married has also been approached as a family, not to carry out the practice of marrying a sirri for various reasons.
} 
contract or agreement which results in halting husband-wife sexual relations between a woman and a men. So that in the language of the Qur'an, marriage is an effort to create a close relationship between a husband, wife also their children and their parents. So a family atmosphere of sakinah, mawaddah, warahmah is formed, in line with Surah Ar-Rum 30 verse $21^{9}$.

As for the normative juridical basis, marriage is in surah AnNisa' which is defined as the achievement of happiness between husband and wife with the provisions of Islamic law, that uphold the value of justice to achieve common goals. Another goal of marriage is to obtain legitimate offspring and obtain pious children who guarantee the happiness of prayer for their parents, after their death. This reasoning is based on the hadith of the prophet narrated by Imam Muslim that when Adam's child dies, his business will end, except for 3 cases, namely almsgiving (jariyah), useful knowledge, and pious children who pray for their parents ${ }^{10}$.

Furthermore, regarding the terms of harmonious marriage, based on the opinion of the ulama, it is stated that the consent process is valid, if the husband and wife replace both of them. There is a guardian and witnessed by two fair witnesses. The terms and conditions of marriage include the existence of a prospective husband and wife who is mature with reason and runs a marriage with free consent. There was a guardian for the bride and groom that was attended by two witnesses who they were free. There must be a dowry from the man to the woman or wife. Finally, the consent of the qabul, and it is hoped, that there will be an official marriage guardian in the marriage contract as a form of giving information for marriage ${ }^{11}$.

The requirements for a husband or wife are clearly good people, women or men, who are not currently doing hajj or performing the umrah pilgrimage, the prospective wife is not in an old state, the prospective husband or wife is a Muslim Muslim, between the two there is no mahram relationship. He is forbidden for the parties to

9 Soemiyati, SH., Hukum Perkawinan Islam dan Undang-Undang Perkawinan (UUP No. 1 Tahun 1974), (Yogyakarta: Penerbit Liberty, 1982), 33-38.

10 Mazhar, Memaknai Hukum Perkawinan (Nikah, Talak, Cerai Dan Rujuk) Menurut Islam Undang-Undang Perkawinan No.1 Tahun 1974, Undang-Undang No.7 Tahun 1979 (UU Peradilan Agama) dan Kompilasi Islam, (Bandung: Mizan, 1985), 90-95.

${ }_{11}$ M. Idris Ramulyo, Hukum Perkawinan Islam. (Jakarta, 1996), 50-53. 
become husband and wife prohibits, this because of the relationship between the two brides of the bride and groom, because of a family relationship such as mother, grandmother and so on. Other reason is as children, grandchildren and so on, sisters one mother and one father, or one and one mother only, aunt. Then from the niece, whether she is coming from the direction of a brother's child or a sister's child.

Another relationship is due to mushaharoh (ordering): stepmother, son-in-law, stepchildren when father and mother have gathered. Other relationships include breastfeeding is ; a breastfeeding mother, one breastfeeding child, a breastfeeding sister, a breastfeeding sister, a breastfeeding sister, a breastfeeding brother's daughter, a breastfeeding sister's daughter. Another reason is because of a combination of men who have been prohibited from marrying their sisters, their aunts, either their father's or their mother's siblings ${ }^{12}$.

The order that has the right to become a guardian is from the direction of the father, grandfather and so on upwards. Then a brother of one mother and one father, a brother of a father, a son of a brother of a brother of one mother and one father, the son of a brother. The father's brother, the mother's brother and the father's brother the same father, the son of a brother as old as one mother, the brother of the same brother, the grandson of the uncle of the same mother, the grandson of the uncle father, father's uncle is a brother of one mother and one father, uncle father is one father, uncle father's mother's son, father's uncle's son, father's uncle's son, grandfather's uncle is a one mother, grandfather uncle is one father, uncle grandfather's son is one mother, the guardian of the judge.

The guardian of the judge is the representative of the guardian who is appointed in a marriage, if various conditions occur, such as when the bride no longer has a guardian by the lineage. Another condition is if there is a dispute between the guardian and the bride which causes the guardian not to marry adlol. And the guardian of the judge can be appointed, if the closest guardian himself has traveled far and has exceeded the distance of the journey (masafatul qosri) where is often around $92.5 \mathrm{~km}$. Or if the guardian is unable to marry off his own daughter, for example The guardian cannot be contacted (imprisoned), the guardian of the marriage is performing ihram (haj or umrah), the

12 M. Idris, Hukum Perkawinan Islam, 77. 
guardian of marriage is tawafu (hidden), the guardian of the marriage is taadzur (obstructed) ${ }^{13}$.

\section{Conception of Marriage Under the Hand in Legal Struggle in Indonesia}

From a sociological perspective, marriage in Indonesia is triggered by four factors, namely: First, it collides with positive legal rules. Marriage under the hand is done to avoid convoluted bureaucracy and may be difficult to be done (Nelson, 2006). This problem can be seen in four conditions, namely legitimate because of the fulfillment of the prevailing laws and regulations. Mixed marriage is a marriage between two people with different nationalities. This requires quite complicated administrative requirements, because it involves the laws of the two countries, especially the management of the citizenship concerned. Do not have official status as a citizen (identity card-KTP).

This case occurs for marginalized urban groups who live in big cities. Regarding regulations, such as female civil servants cannot become the second wife, third and fourth wives (PP 10/1983 junto PP 45/1990). Regarding school regulations, for example, they are still registered as high school students or others. Second, is the cause of psychological factors. Marriage sirri is carried out because it takes into the psychological factors, which occur when a person has reached the requirements. And from an economic point of view, there are no problems, but there are obstacles that have not been resolved, such as still continuing to study or still at the Islamic Boarding School.

For the act of marriage that is carried out in a sirri manner, it is intended to avoid immoral behavior and the sin of marriage like this, usually an agreement made between the married parties, such as not yet getting together like a husband and wife, or they do not have children before the specified time. The third other economic factors, such as underhand marriage (sirri), are the background for workers who live in areas where foreign workers are available and have a higher variety of incomes than the original population. According to Kahmad (2010), local women get married without a record to get a decent economic source. Likewise, it becomes an economic obstacle for men

13 Wahbah al-Zuhaili, Al-Tafsir al-Munir, 83. 
who are less able to take care of the administrative costs of marriage registration by officers, which are quite expensive ${ }^{14}$.

Fourth, the tradition factor. A tradition carried out from generation to generation which considers under hand marriage as "customary", practical and economical, so there is no need for formal legal law. Among the scholars or kyai in various regions claiming the marriage contract is valid without registration at the marriage registrar (KUA). They argued that with their marriages during the leadership of the prophet Muhammad and his friends, their marriages were not registered. Thus, it is sufficient for the marriage contract to be carried out through the permission of the guardian of the bride and the presence of two witnesses.

The Islamic scholar (ulama salaf) gave a description of the contract marriage as a pattern of marriage, where there are no witnesses or witnesses but the bridegroom gave the witnesses' request to keep this marriage a secret. In the Maliki school (mazhab), mut'ah or contract marriages can be treated fasakh, namely divorce of bain, If the husband and wife have committed sexual acts or both partners can be given zina which can be in the form of stoning or binding. This is when there is an intercourse between them and they admit that the relationship is proven by 4 witnesses as witnesses in licensing.

The two couples cannot be given the right, if they have given news of the marriage, either through a reception or other news with one witness outside the marriage witness and the guardian. From the Hanafi school of thought (mazhab) that the marriage was a contract that could not be canceled through a request for the confidentiality of the marriage, if a guardian and witness and also the husband and wife kept it a secret.

As for the Maliki school (mazhab), they provide similarities between marriages that are carried out without witnesses through a marriage contract or by a husband-wife couple asking witnesses to keep their marriage secret in the form of a marriage contract. This is considered a contract marriage and can be invalid, but according to Imam Hambali, they provide a legal consequence distinction that the

${ }^{14}$ Mazhar, Memaknai Hukum Perkawinan (Nikah, Talak, Cerai Dan Rujuk) Menurut Islam Undang-Undang Perkawinan No.1 Tahun 1974, Undang-Undang No.7 Tahun 1979 (UU Peradilan Agama) dan Kompilasi Islam, (Bandung: Mizan, 1985), 112-114. 
two forms of the marriage contract are legally different. If a marriage is witnessed, but there is a request from the bride and groom to keep it secret, then the contract is still valid. If the marriage is not witnessed by witnesses, then the marriage is considered invalid.

Within 4 days of their agreement, the witness becomes a legal condition for a marriage and does not become valid, if there are no two witnesses other than the guardian of marriage. However, the presence of two witnesses can be a condition when one marriage is taking place. According to Imam Hanafi, Imam Shafi'i, and Imam Hambali are of the opinion, that the two witnesses must have real proof of the on going marriage. As for Imam Malik, the view is that it is permissible for a marriage, where there are no two witnesses when it takes place. But the husband and wife relationship must be witnessed by two people and the notification is announced that their marriage has been carried out.

A contract marriage is a marriage that is more popular with a marriage contract that is not registered at the religious sffairs office (KUA). In the perspective of state law, this is referred to from Islamic law in national legislation (the law on marriage number 1 of 1974), according to this marriage law in paragraph 1 article 2 , states that a new marriage is declared a legal marriage, when it is carried out on the basis of on religious regulations and beliefs of their respective partners. When referred to from article 2 paragraph 1, then it is also explained that the marriage law is the process of submitting in full to the religious regulations of the legal provisions of a person's marriage.

Based on these regulations, the marriage which is carried out by a married couple who has fulfilled the requirements and harmony in religion, the law of marriage is valid and children born from the husband-wife relationship are also declared as a legitimate children. Children born from such a contract marriages or underhand marriage (sirri) are still a matter of debate among experts.

Based on the compilation of Islamic law (KHI), in article 4 states that according to this marriage law in paragraph one article 2 , it is stated that it is a legal marriage when it is carried out based on religious regulations and the beliefs of the respective spouse. A legal marriage is a marriage that is reported and registered either at the KUA or in the civil registry for those who do not embrace Islam. Thus, the provisions in paragraph 2 article 2 of the marriage law also confirm that marriages must be registered based on the prevailing statutory regulations. 
Based on the basis of the compilation of Islamic law, it is stated that in order to ensure orderliness in a marriage, the muslim community is obliged to record the marriages they have performed. The marriage registration process based on paragraph 1 is carried out by employees who register marriage. Likewise in law number 22 of 1946 Jo. Law number 32 of 1954 regulates the same thing. Thus, without a marriage registration, the child born to the couple only has a legal relationship with the mother or has a family relationship with the mother.

In the marriage law, precisely in article 42 , also if it is stated that a legitimate child is a child born in or as a result of a legal marriage in paragraph 1 article 43 it states that "Children born outside of marriage only have a civil relationship with their mother and family from his mother ". So in article 186 in the compilation of Islamic law the child inherits only from the direction of the mother ${ }^{15}$.

As for children born out of wedlock, those who do not have recognition as the heirs of their father are based on the decision of the constitutional court number 46/ PUU.VIII/ 2010 which examines article 43 paragraph 1 of the marriage law. Children born outside of marriage have a civil relationship with their mother as well as with men as his father who can be given proof based on science and technology or through other evidence based on the law which is related by blood includes a civil relationship with his father's family.

So, children born from Underhand marriage (sirri) must be able to prove themselves as biological children who have inheritance rights. This is reflected in Article 285 of the Criminal Code which explains that when there is recognition from the father, it can cause a legal relationship in the inheritance of the child out of wedlock, it is not permissible to give harm to the wife or biological children of the heir itself.

The behavior of not carrying out the registration of marriage even though the marriage process is carried out based on Islamic law is considered an act of smuggling the law, namely behavior of not obeying the law in the context of the State of Indonesia as a rule of law. So, all Indonesian citizens should obey the rules of law in force in this

15 Kanal Mukhtar, Asas-Asas Hukum Islam Tentang Perkawinan, (Jakarta: Bulan Bintang, 1974), 56-79. 
country. The law number 1 of 74 , is the law of the Indonesian state that has legally provided rules for marriage for its citizens.

Marriages that are done without obeying the rules of the marriage law can have an impact on their property and offspring. Inheritance, in this case, falls to the child who will inherit. Likewise, marriages that are carried out in a sirri manner have no power before the law. Even they are not recognized by the state in the event of material problems or disputes over joint property, such as inheritance rights to property owned by their father and cases requiring other legal legality.

Problems with inheritance rights or other issues require filing, before a religious court cannot be decided, because these legal issues have no basis in terms of the status of children born from underhand marriage (sirri). This is because the child as a child does not have authentic evidence as a legal basis for a legal marriage. So this status has an impact on the legal side of the child's inheritance rights, namely children who do not have recorded recognition by the state. The state cannot help in the process of solving problems arising from the existence of a underhand marriage (sirri) by a married couple. This includes the inheritance rights of the children they give birth to.

As in the context of the State of Egypt, Law number 78 of 1931 which regulates al-Mahakim asy 'Syar'iyah which gave rise to the term azzawaj Ar urf (underhand marriage). Article 99 confirms the existence of a lawsuit which is related to marriage and the rights related to the marriage, namely the court or a court that cannot accept. Unless the marriage can be legally proven through a marriage certificate based on the Egyptian law. There is a provision which mandates the legal registration of marriage to the officers of the marriage registrar who are legally and formally assigned the duty to register all the marriage process of its citizens.

In the context of the enactment of this law in Indonesia, a legal marriage is a marriage that is registered at the religious affairs office so that marriages run by the community obtain a formal legality and also provide an impact on the protection of the rights of wives or the rights of children born from a legal or this legal marriage ${ }^{16}$.

16Wahbah al-Zuhaili, Al-Tafsir al-Munir, 76-83. 


\section{Underhand Marriage: Concepts and Practices in Pesisiran Jawa, South Pati}

Among the findings research of this underhand marriage was a marriage legalized by the Sumatran Customary Head for Tondomulyo Village residents, which was signed by the village head in collaboration with the Jakenan District. Two polygamous marriages with fake marriage certificates quoted from residents of Sendang Soko Village and Kedungmulyo Village. When the rejection of the request for marriage, the prospective village bride is due to lack of requirements or is not yet aged.

The findings of other data on the practice of these underhand marriage (sirri) were also carried out by some people in the village of Tambaharjo, South Pati, where on average, they have no depth knowledge of underhand marriage law regulations. From several interviews with the couples, underhand marriage (sirri) in this village can be seen that most of them have a reason to run a marriage. They know that this sirri married on Islamic religious law is considered legal and a legal marriage.

This is the basis for the reason why the underhand marriage inauguration is general in nature, so it is related to the process of recording a marriage in the religious affairs office and also the existence of its publication, which is essentially to achieve maslahah in a sociological perspective. So the law can be used as socio-religious control of the various changes that occur in the midst of society. This law can be replaced by a tool to create engineering in the midst of social society to realize the goodness and welfare of the community. Based on research on 10 sirri married couples, this was obtained through indepth interviews in several villages in the sub-district of South Pati 17.

The reason for the marriage they used was because of a suggestion from a trusted religious figure besides that because it was personal. This is because the female partner who has been declared legal does not give permission. Brother $\mathrm{P}$ is 40 years old who is from the next village who has a profession as a farmer and also brother $\mathrm{S} 18$ who comes from the next village has a job as a trader they do not gather

17 Wahbah al-Zuhaili, Al-Tafsir al-Munir, 76-83.

17 Interview with the staff of the Office of Religious Affairs, in Jaken District, Pati district 18 The names of the wedding couple in this article are made with the initials to maintain the comfort of the married couple. 
immediately then they have the desire to get married legally, but because there is a condition in the economic aspects of both of them not enough then the financing of the marriage to officially end up their choice is by way of nikah sirri ${ }^{19}$.

There is a situation of getting married or gathering together as husband and wife that occurred in Plosojenar village because of old age. The existence of unprocedural marriages in Sidoarum village on the grounds that each party is afraid of losing their pension rights ${ }^{20}$. Marriage under the hand can generate various positive perceptions for certain circles, however for certain circles it can bring up many things that are not positive, especially for women.

The perpetrators of an underhand marriage can be seen from several aspects including age and even social status. This is manifested in the practice of sirr marriage by the majority of the people in the village of Addarjo, Pati, South, who on average have a uniform level and knowledge of the law of underhand marriage regulations varying from several interviews with underhand marriage (sirri) in the village. It can be seen that most of them have reasons to carry out an Islamic marriage which has been legalized as a legal marriage.

This is the basis of the reason why the underhand marriage inauguration is general in nature, so it is related to the process of recording marriage in the religious affairs office and also the existence of its publication, which is essentially to achieve maslahah in a sociological perspective, the legal tomb can be used as a socio-religious control of the various changes that occur. In the midst of this legal community, tools can be replaced to create engineering in the midst of social society to realize the good and welfare of society. So, based on the research, 10 sirri married couples were obtained by means of indept interview in several villages in Pati Selatan Subdistrict ${ }^{21}$.

\footnotetext{
19 Observation in one of the villages in the coastal area of South Pati.

${ }^{20}$ Data from Jakenan Subdistrict, marriage certificate documents.

${ }^{21}$ Based on the information from the head of the KUA of Winong sub-district, Ali Mahmudi, who used to be a marriage registrar in Jaken sub-district, cases of unregistered marriages that have been rampant in the past are on average because they are supported by religious figures who are willing to marry in a sirri manner.
} 
From the research data that has been conducted, including data from a pair of friends from Kayen village, $\mathrm{Zhd}^{22}$ (48 years), still has an official wife and Zbd (48 years), a widow from Runting Village. Both have livelihoods as brokers and traders. The reason for the marriage that they used was because of a suggestion from a trusted religious figure. Besides that, Zhd still had a legal wife but until now he has not been gifted with children. Other research data also includes a widower from the village of Runting who works as a driver, A (54 years), and W (41 years) a widow from Jepara.

The reason they got married under hand was to avoid slander in society, because they had often been together. Another pair of research results showed that there was a marriage of someone who was a craftsman, S (38 years old), and $\mathrm{M}$ ( 27 years old) came from the village of Beran. The reason, they are married under the hand, is to find peace of life where $\mathrm{S}$ lives alone and $\mathrm{M}$ is with her grandmother, while her parents transmigrated to Lampung.

There is also data from the research results, on the marriage of a couple whose husband is a driver $S$ ( 52 years), has a legal wife, and S (48 years), both of whom come from Runting village. The reason for getting married under the hand, the female partner who has been declared legal did not give permission. Brother $\mathrm{P}, 40$ years old who is from the next village has a profession as a farmer and also $S$ who comes from the next village, has a job as a trader.They do not to live together without being married (kumpul kebo), actually they have the desire to get married legally, but because there is a condition in the economic aspects. Both of them not enough then the financing of the marriage to officially end up their choice is by way of underhand marriage (sirri).

There is also a young couple, whose initials N (21 years) comes from Runting, and D (22 years) comes from Tayu. Both are still studying in one city. The reason they married under their hands was because they thought that marriage would be troublesome for their study process. $\mathrm{Y}$ ( 25 years) comes from Salatiga, and $\mathrm{T}$ ( 23 years) comes from Beran. The two are still studying at Atlas city. The reason they got married under hand was because they felt ashamed of the public rumors about being married and without the knowledge of the male

22The names of the wedding couple in this article are made with the initials to maintain the comfort of the married couple. 
parents. This desicion is done so that the tuition fees from parents still continue ${ }^{23}$.

According to the statement of several heads of the KUA, in different areas in the coastal areas of North Java, that the various reasons for marriage are very much influenced by the regions in Pati districts. In general, the great religious leaders (kyai) in the northern coastal areas of Java, for example Kyai Abdullah Salam from Pati, kyai Ulin Nuha Kudus and kyai Maemun Zubar, from Rembang, those who were charismatic kyai did not want to be witnesses of marriage or even as representatives of marriage, except after marriage registrar (naib) was present. This means that these religious leaders (kyai) firmly hold on to enforcing marriages that are officially recognized by the state. Ethically or morally, they are more concerned with the greater benefit of legally registered marriages.

Based on this description, there are two social facts that there are two types of marriage; those that are still tangible, visible, observable material. There also are non-material forms such as social phenomena that occur within humans themselves born from the roots of human consciousness. By analyzing the actions of the couples of underhand marriage (sirri) in Pati district, it can be argued that this is rational behavior, because the marriage is carried out with their logical and conscious considerations.

Rationality is related to the goals and tools used. The behavior of an underhand marriage cannot be categorized as a non-rational act, either in the traditional or affective sense. It cannot be said to be a traditional action because it is not or is not a habit that is done consciously and with consideration ${ }^{24}$. Likewise, the decision to marry under the hand cannot be categorized as an affective action, because that action is not controlled by a sense of self-emotion which is not reflected in a rational way or based on a well-thought plan.

If there is intercourse between husband and wife, then it is allowed. But if the second marriage has not yet occurred, fasakh process can be carried out. According to many views, scholars emphasize the

${ }^{23}$ Interview with the head of the KUA, in Winong sub-district, Jaken which is in the district of Pati Regancy.

${ }^{24}$ Analysis of Under-Hand Marriage and Its Causing Factors in Tambaharjo Village, Pati Regency, (Research Results). Pp. 67-197. 
urgency of witnesses being present in the marriage contract to maintain a balance of the rights of women and children who are born. This anticipates the existence of denial of responsibility and the inability to acknowledge children resulting from their marriage, this is not the case, this is also the cause of the child being neglected without having a clearer lineage.

The presence of witnesses in this marriage can be a precautionary step to avoid accusations of accusations. It is not justified in the husband and wife couple. In fact, contract marriages that occur quite a lot in the current era are different from the underhand marriage (sirri) pattern which is seen by past scholars ${ }^{25}$. Marriage is a form of nature law (sunatullah) and Allah which provides a way for humans to develop the good qualities chosen by God as a medium that develops in terms of goodness and is able to provide lasting power for life. As a way for humans to reproduce and to sustain their life. As Allah SWT says in surah An-Nisa verse 1.

In a marriage there is a contract (agreement), which is the hand over between the parents of the prospective bride and the prospective groom. A contract is to legalize between husband and wife in relationship and the limited rights and obligations of both husband and wife. It is to help each other between various parties who are not the previous mahram. As is the law of marriage in the Indonesian context as stated in the marriage law number 1 of 1974 . Underhand marriage is also considered by some people to try to avoid themselves from the system and ways of regulating the implementation of marriage according to Law No.1 of 1974, which is bureaucratic and complicated. winding and the length of time to handle it.

Marriage is considered valid if it is carried out according to the positive law of the state, religion and belief based on paragraph 1 article 2 of the marriage law. Muslims who carry out such regulations, the marriage contract will still have the position of the legality of the marriage bond both legally and socially. This is because the marriage is carried out with the presence of male and female prospective friends

25 Juwahir Tantowi, Praktik Nikah Sirri Dalam Sistem Hukum Positif Indonesia, Makalah Sehari tentang Nikah Sirri dalam Pandangan Syariat, Hukum Positif dan Psiko Sosial, di Auditorium UII Pusat, 22 April 2001. 
who are muslim and then give an expression consent. And they are not hindered by a marriage by paying a man's dowry for his future wife

This provision normatively is explained in Quran, surah AnNisa verse 4 apart from being based on the hadith of the prophet Muhammad that a legal marriage is when there is a female guardian and two fair witnesses. As for the requirements of the guardian of the woman who is married, it becomes valid when the guardian is a muslim and has reached puberty.

In the perspective of Islamic law, based on surah al-Baqarah verse 282 and also based on surah an-Nisa verse 21 , namely that legal marriage is according to Islamic rules when it fulfills various conditions and pillars either materially or must also be data and registered by the interpreter. note the fair (kaatibun al-fair). By state law, the registrar of marriage has been appointed by the government which manifests in the task of registering divorce and reconciliation. This is based on law number 22 of 1946 in conjunction with law number 32 of 1954 concerning employees who register marriage or a leader (qodli).

Constitutional Court stated about the prohibition of underhand marriage (sirri) in the laws of the religious court. Even he gave direct approval to the perpetrators of underhand marriage (sirri) to be charged not criminal, because it caused the children to be neglected or the first wife was not given a point recognition. The Constitutional Court also gave a statement approving the underhand marriage (sirri) which was considered to have many bad effects and losses.

This statement is in line with what was conveyed by the former head of the Constitutional Court, Mahfudz, that the prohibition of underhand marriage (sirri) in the religious court legislation gives direct agreement that the couples of underhand marriage (sirri) can be charged not criminal, because they cause neglected children or their first wife do not deign to confess. Agreeing with the Constitutional Court, this is the same as MUI, namely Ma'ruf Amin also gave a statement approving the underhand marriage (sirri) which is considered to have a lot of harm (madarat) or loss.

Those who provide support for this assessment have indeed had an impact on various parties, especially the rights of children to inherit, this was also responded to by the former Minister for Women's Empowerment, Mutia communicated that this sirri's marriage had a big negative impact on women and children. Therefore, if both parents 
divorce or pass away, their inheritance cannot be given. Their rights just disappear, because based on the positive law of the country, these children do not get other inheritance rights legally before the law.

Jimly Asshiddiqie also responded to the draft law regulating crimes for couples of underhand marriage (sirri) because they consider that the presence of the state is also responsible for providing administrative order for the traditional actions of every citizen. Jimly gave an assessment that sirri's marriage is an identification of the hidden adultery practice. Therefore, the Ministry of Religion also provides a form of affirmation that underhand marriage (sirri) are considered illegitimate and can be considered as a process of adultery.

In this case, the husband and wife who have carried out a underhand marriage (sirri) must validate and record their marriage before the marriage registrar at the religious Affairs office (KUA) or civil registration. Therefore, underhand marriage (sirri) are considered religiously valid, but that does not mean that the legality of their marriage can work equally. The Ministry of Religion affirmed that the government has proposed a draft law on the material of religious courts on underhand marriage (sirri) which gives legal force to the couples to criminal sanctions.

Suryadharma Ali personally stated that the underhand marriage (sirri) can be declared religiously valid. However, the government provides a regulation on the invalidity of their marriage before the law, because it violates administration. So this must be noted in addition, that the underhand marriage (sirri) also has a negative impact, such as when a woman is pregnant, the child does not have a written bond related to inheritance or other laws, men can act arbitrarily against women in one such underhand married (sirri).

According to research from Nur Fadhilah, in feminist opinion, underhand married (sirri) is more negatif impact (madarat) than positive impacts (maslahah) ${ }^{26}$. Our society should be educated about the negative impacts and the children that will be born later. Marriage under the hand because it is not legal before the law of the country, so children are prevented from obtaining their rights. For example, in relation to share assets (gono-gini), if one day there is a divorce, because whatever happens the marriage will be deemed never to have

26Nur Fadhilah, Perkawinan di Bawah Tangan (Nikah Sirri) dalam Perspektif Feminis, 2015. 
happened by the law. Socially, marriage under the hands is often considered as cohabitation behavior (kumpul kebo), that couples live together without being married. This is because a husband and wife from a underhand marriage (sirri) do not have an official marriage bond before a marriage registrar which is legal under state law.

Another negative impact of this underhand marriage (sirri) is the difficulty for children before the law, when they have to take administrative actions. In the status of children from the result of a underhand marriage (sirri), they are not considered valid, because this child is considered to have no lineage from his father and only has a line to his mother. So a child who is not related to the father cannot obtain the right to support or finance life is included in the election, education and inheritance rights from his own father. This underhand marriage (sirri) case certainly has a negative impact on children, including access to a birth certificate which is an official document in the care of needs in the context of the Indonesian state.

Borrowing Weber's view ${ }^{27}$ that the individual's actions basically also have special goals and values. This is a manifestation of the effort to understand an action and at the same time understand the purpose of the action. So that in understanding a society's action, one should understand the context of the meaning or value in the culture of a society itself. Weber offers to understand it with his interpretative concept. So, it is possible to first understand the meaning of the underhand marriage itself ${ }^{28}$.

In a research result, it is found that underhand marriage (sirri) is related in the view of feminists, where there is often no gender equality in it. Gender in this case is able to position a man and woman equally in all things. So, if there is an effect from underhand marriage, the our socities already understand and are educated on gender will take precautions. However, the opposite will happen if gender-related education cannot be carried out massively. Of course, gender perception of course will still appear in people's lives if this happens.

27Weber, Max, Law Economic and Society, (Edward Shils dan Max Rheinstein (tld) New York Simon and Schuster, 1954),.12.

${ }^{28}$ Muhaimin, Praktik Nikah Sirri di Msayarakat Islam DIY, Mimbar Hukum No.20 Tahun 1994. 
This is very crucial to be discussed again, because the initial symptom of gender perception is the placement of women as objects of men.

In this case, especially women become an outlet for male lust. Marriage sirri is very gender effected if the understanding of gender is not yet complete. As for the Marriage Law Number 1 of 1974 and also in the Compilation of Islamic Law, there are several points that do not provide equal space for women. For example, there are points against women who are deemed not fulfilling a sense of justice and humanity, even though when viewed in the development of the marriage law, there have been some progress.

Some of the problems by Siti Musdah Mulia in several of her writings are explained. First, Musdah Mulia stated related to the right of the bride which was later replaced by the authority of her receiving consent by the guardian in a marriage. Second, there is a provision that must be secreet (sirri) with people who are of the same religion, so that there is a pseudo controversy and the assumption that after marriage they will return to their respective religions. Third, regarding the age limit stated in Article 7 paragraph 1, the minimum age limit is 19 years for men and 16 years for women. According to Musdah, this contradicts Law No. 4 of 1979 concerning Child Welfare, in which Article 1 paragraph 2 states that, "A child is someone who is under 21 years of age or who has never been married".

Fourth, the problem of marriage registration that does not come under pressure or there is a necessity or there is a sanction if it is not implemented. Even though if it is not implemented, it will have an impact on the labor for the bride and groom themselves, especially his wife and children. Fifth, in relation to polygamy, where ever in the law of marriage, it is said that marriage adopted in Indonesia is based on monogamy, but in fact polygamy is allowed for several reasons.

In the Law No. 1 of 1974 describes polygamy which is regulated in detail in articles 3, 4, 6 which are further construed in that article as the interests of men, even though in the Qur'an what it is talking about is orphans. According to several figures who have a gender perspective, there are marital problems contained in the Law No. 1 of 1974 is a form of view that adheres to the concept of culture as well as sociologically and has discriminated against women. Subordination accompanied by discrimination occurs against women due to gender inequality, in addition to social and cultural constructs which are then 
able to differentiate between roles, behavior, mentality and emotional characteristics between a man and a woman who has developed in society at large.

The process of the syiar marriage is also important in family life to anticipate unfavorable public perceptions of other community members that where allow for social interaction between the opposite sex, namely a man and a woman to do not have a mahram relationship. Based on Islamic law and positive state law, the legal marriage, if it is carried out before the PPN, as authentic evidence of the shares of the marriage, is in the form of a marriage certificate where a person with a marriage certificate provides benefits and benefits to himself and his family, both his children and his wife. The functions of other marriage certificates can also anticipate the rejection of the probability that occurs when someone later breaks their marriage contract or the legal consequences of a marriage. It is carried out either on joint property or inheritance from the result of a marriage.

A part from that, another benefit of this marriage certificate is to provide protection from accusations of adultery or other slander. Thus, a marriage process is more problematic when the marriage is recorded in accordance with the maslahah mursalah rules. From a juridical or positive legal perspective, the conditions of marriage are also recorded in the marriage law in article 2 paragraph 1 PP number 9 of 1979 , which contains the implementation of the marriage law ${ }^{29}$.

The results of other studies that interviewed several informants of the couples of underhand marriage (sirri), the majority of them, stated that the formal legality or Islamic sharia law of marriage is valid, if it fulfills the conditions of the harmonious marriage. The terms of harmony in question are the presence of the bride and groom. There were two people who testified fairly, it was a marriage agreement (ijab qobul), the presence of a female guardian and the existence of a dowry in the marriage. Based on other research, on 29 married couples in the Ngawen region, the majority reasons of married under hand (sirri) included the high cost of procuring a wedding reception celebration.

In the context of culture and tradition in the northern coast of Java, Pantura area, marriage is carried out through the process of

29 Analysis of Under-Hand Marriage and Its Causing Factors in Tambaharjo Village, Pati District, Pati Regency, (Research Results) , 67-197. 
binding a gift ring exchange in the wedding procession. When giving the dowry, many of the neighbors are present and because of that, the wedding becomes a big family celebration event which requires a lot of money. Another factor that also covers the rise of married under hand (sirri) is the economic situation of a married couple. Most of them relatively have an income that is only sufficient for their daily needs. While for financing, they are registered at the religious affairs office, Some of which do not have the same fee as the rate given by the affairs office religion (KUA).

Other factors are the problem of the study problem, so that the main reason for these learners or students is the difficulty in terms of financing to study and at the same time to hold a wedding procession. The existence of a marriage process is a separate force in the middle of the study and gives a perception of shame from society, when this couple is still in youth status either given by the surrounding community or their college environment ${ }^{30}$. Thus, the orientation of those who feel marriage is more dominant in economic factors.

From a religious perspective, the presence of religion actually plays a role in providing solutions to the problems of the people that often arise in society. It is not only empirically in the field but also must be done comprehensively. Religion in this case has a very strategic position to be present to provide a sense of security and reassurance for its adherents. Getting married in a sirri is actually one of the sense of security solutions for young people who want to perfect their religion without having to be burdened with the large amount of money involved in having a wedding 31 .

In this condition, of course, marriage under hand (sirri) is not a solution in the long term, so underhand marriage (sirri) can be a solution for the short term. It is that their anxiety over bad interactions is saved, in this case it is a relationship that is not justified by religion only, but in the long term ideally a married couple who being in a

\footnotetext{
30 Interview with Ali Mahmudi, Head of KUA, Winong Subdistrict, Pati Selatan, there is a married couple who are still studying and are registered at the KUA Winong subdistrict.

31 Achmad Nurseha, Tinjauan Hukum Islam Terhadap Praktik Nikah Dibawah Tangan (Studi Kasus Di Kecamatan Ngawen Kabupaten Blora), Jurusan Ahwal Al-Syakhshiyyah, Fakultas Syari'ah, Universitas Islam Negeri Walisongo, Semarang, 2015, hlm 1-97.
} 
marriage bond sirri should register their marriage in front of a marriage registrar employee.

\section{Conclusion}

With the existence of complete legislation in the Indonesian context, Muslims can carry out the Islamic legal order while continuing to carry out positive legal legislation. This does not have to be confronted between various laws in an Indonesian context, but it can complement and enhance one another. In the case of marriage in the perspective of Islamic law which is considered valid, but on the positive side of the state law, it is declared not valid, it can be compromised by the ease of bureaucracy and flexibility in understanding social axioms. Underhand marriage (sirri) actually have many prolonged debate.

With this condition, it is necessary to have public awareness to be open with information and discipline in the implementation system from the authorities, so that the glory of marriage is not hindered and on the other hand is the prevention of the damage (madarat) that can be caused later. In the context of the coastal communities of Java in southern Pati, there are various implementations of underhand marriage (sirri) which in fact do not heed state regulations. The implementation of this marriage is still not supported by a strong awareness from each party. Therefore, it is very important to build awareness together in enforcing legal compliance, especially in the implementation of Islamic family law, marriage in Indonesia context.

\section{Daftar Pustaka}

Al-Bagha, Musthafa Daib, Fiqh Syafi'i, Terjemahan St.Tahdziib, Surabaya: CV. Bintang Pelajar, tt.

Al-Nawawi, Abdul Al-Khalik, Al-Aqalat Ad-Dauliyyah An-Nuzum AlQadariyyah Fi Asy-Syari'ah Al-Islamiyah, Beirut: Dar Al-Kutub AlArabi, tt.

Al-Tabari, Abu Ja'far Muhammad Ibn Jarir, (tthn), Tafsir At-Tahri AlMusmmajani Al-Bayan Fi Ta'wil Al-Qur'an, Beirut: Dar Al-Kutub Al-Ilmiya, tt.

Al-Zuhaili, Wahbah, Al-Tafsir al-Munir Fi al-Aqidah Wa al-Syari'ah Wa al-Manhaj, Beirut: Dar Al-Fikr Al-Muasir, tt. 
Analisis Nikah di Bawah Tangan dan Faktor Penyebabnya di Desa Tambaharjo Kecamatan Pati Kabupaten Pati, Skripsi.

Buku Laporan Tahunan KUA Kecamatan Jakenan Tahun 2000 Diktat Menjelang Nikah, BP4 Kab.Pati, 1979.

Denzin, Norman K. dan Yvonna S. Lincoln (eds.), Handbook of Qualitative Research. Terj. Dariyatno dkk., Jogjakarta: Pustaka Pelajar, 2009.

F.A Volman, Hukum Keluarga Menurut KUH Perdata, Bandung: Penerbit Tarsito, 1990.

Hamid, Zuhri, Pokok-Pokok Hukum Perkawinan Islam dan UndangUndang Perkawinan di Indonesia, Yogyakarta: Bina Cipta, 1976.

Interview with Acting KUA, Jakenan District, Pati Regency

Interview with religious figure

Interview with the Head of KUA, Pucakwangi District, Pati Regency

Interview with the head of the KUA Jaken district, Pati Regency

Interview with the Head of the KUA, Winong Subdistrict, Pati Regency

Irfan, Nurul, hasil Penelitian dengan judul Kriminalisasi Poligami dan Nikah Sirri, 2011.

KUA Kecamatan Jakenan, Dokumen Akta Nikah, 1999-2003.

Madani, A. Malik, Nikah Sirri Dalam Perspektif Fakultas Syari'ah, Yogyakarta: IAIN Sunan Kalijaga, tt.

Mas'ud, Hasil penelitian dengan judul Dampak Nikah Sirri Terhadap Hak Waris Anak Dalam Perspektif Fiqih Dan Hukum Positif.

Mazhar, Memaknai Hukum Perkawinan (Nikah, Talak, Cerai Dan Rujuk) Menurut Islam Undang-Undang Perkawinan No.1 Tahun 1974, Undang-Undang No.7 Tahun 1979 (UU Peradilan Agama) dan Kompilasi Islam, Bandung: Mizan, 1985.

Mudhar, A. Zuhdi, Memahami Hukum Perkawinan Islam, Yogyakarta: AlBayan, 1994.

Muhaimin, Praktik Nikah Sirri di Masyarakat Islam DIY, Mimbar Hukum No. 20 Tahun 1994.

Mukhtar, Kanal, Asas-Asas Hukum Islam Tentang Perkawinan, Jakarta: Bulan Bintang, 1974.

Nasution, S., Metode Penelitian Naturalistik Kualitatif, Bandung: Tarsito, 1996.

Nurseha, Achmad, Tinjauan Hukum Islam Terhadap Praktik Nikah Dibawah Tangan (Studi Kasus Di Kecamatan Ngawen Kabupaten 
Blora), Jurusan Ahwal Al-Syakhshiyyah, Fakultas Syari'ah, Universitas Islam Negeri Walisongo, Semarang, 2015.

Observations in several villages in southern Pati Regancy (Jaken, Jakenan, Winong district)

Ramulyo, M. Idris, Hukum Perkawinan Islam, Jakarta : Bumi Aksara, 1999, Cet. II.

Rosyid, Zaenur, Dinamika Sosial Transformatif Kyai dan Pesantren Jawa Pesisiran, Wonosobo : Mangkubumi, 2017.

Sahlany, Muallif, Perkawinan dan Problematikanya, Yogyakarta: Sumbangsih Offset, 1981.

Sajuti, Thalib, Kuliah Hukum Islam Ii Pada Fakultas Hukum UI Tahun 1977-1978, Jakarta, Kuliah Ketiga.

Saleh, K. Wijk, Himpunan Peraturan Dan Undang-Undang Tentang Perkawinan, Jakarta: PT Iktiar Baru Van Hoven, 1974.

Sastroadmidjo, Astro dan Aulawi, Wasit, Hukum Perkawinan di Indonesia, Jakarta: Bulan Bintang, 1978.

Soemiyati SH, Hukum Perkawinan Islam dan Undang-Undang Perkawinan (UUP No. 1 Tahun 1974), Yogyakarta: Penerbit Liberty, 1982.

Subarman, Munir, hasil Penelitian dengan judul Nikah di Bawah Tangan Perspektif Yuridis dan Sosiologis, dalam Ijtihad, 2013.

Subekti, Pokok-Pokok Hukum Perdata, Yogyakarta: Penerbit PT Intermata, 1994.

Sudarsono, Perkawinan Nasional, Jakarta: Reineka, 1991.

Tantowi, Juwahir, Praktik Nikah Sirri Dalam Sistem Hukum Positif Indonesia, Makalah Sehari tentang Nikah Sirri dalam Pandangan Syari, Hukum Positif dan Psiko Sosial, Di Auditorium Uii Pusat, 22 April 2001.

Weber, Max, Law Economic and Society, Edward Shils dan Max Rheinstein (tld) New York Simon and Schuster, 1954.

Yunus, Mahmud, Hukum Perkawinan dalam Islam Menurut Mazhab Syafi'i, Hanafi, Maliki dan Hambali, Jakarta: PT. Hidakarya Agung, 1983. 